\title{
Evaluation of Suitability of the Regional Spatial Plan At Buleleng Regency 2013-2033
}

\author{
Dewa Made Atmaja ${ }^{1}$, I Wayan Treman ${ }^{1}$, I Gede Budiarta ${ }^{1}$, I Wayan Krisna Eka Putra ${ }^{1}$, Wayan \\ Damar Windu Kurniawan ${ }^{1}$, I Gst. Ngr. Yoga Jayantara ${ }^{1}$ \\ \{made.atmaja@undiksha.ac.id\} \\ ${ }^{1}$ Universitas Pendidikan Ganesha, Indonesia
}

\begin{abstract}
This study aims to evaluate the suitability of land use with the Buleleng Regency Spatial Plan 2013-2033. The method used to evaluate the level of suitability of land use is by comparing the actual land use with the Regional Spatial Plan so that the level of conformity can be seen, referring to the Attachment to the Regulation of the Director General of Land Rehabilitation and Social Forestry No. P.04/V-Set/2009. Determination of the function area is done by adding up the scores of the determinants of the function area, namely soil type, rainfall, and soil sensitivity to erosion. The amount of the score is the score for determining the function of the area. The criteria are protected function areas (A) if the score is 175, buffer function areas (B) if the score is $125-174$, areas with annual plant cultivation functions (C) if the score is 124, areas with annual crop cultivation functions (D) if the maximum score is 124 and micro land has a slope of not more than $8 \%$. Determination of area functions also refers to the Attachment to the Regulation of the Director General of RLPS Number: P.04/V-Set/2009 dated March 5, 2009. Evaluation of the suitability of land use and area functions with the Spatial Plan of Buleleng Regency will provide an illustration of how far the level of suitability/incompatibility of actual land use with the Spatial Plan of Buleleng Regency 20132033 so that it can be a reference for land use planning and area conservation. The results showed that the Buleleng district was dominated by protected areas (A), buffer areas (B) and cultivation areas (C). If we look at its suitability with the regional spatial plan, the existing land use shows a sufficient suitability.
\end{abstract}

Keywords: land use, spatial planning, region.

\section{Introduction}

Buleleng Regency is one of the regencies in Bali Province which has an area of $1,365,88$ $\mathrm{km} 2$ or $24.25 \%$ of the total area of Bali Province, with a beach length of $\pm 157 \mathrm{~km}$. Administratively, Buleleng Regency consists of 9 sub-districts, 129 villages, 19 sub-districts, and 169 traditional villages. Astronomically, Buleleng Regency is located at $8^{\circ} 03^{\prime} 40^{\prime \prime}-8^{\circ} 23^{\prime} 00^{\prime \prime}$ South Latitude and $114^{\circ} 25^{\prime} 55^{\prime \prime}-115^{\circ} 27^{\prime} 28^{\prime \prime}$ East Longitude. The area of Buleleng Regency stretches from west to east with the topography in the south consisting of hills and mountains, while in the north is a lowland along the coast. 
Referring to data from the Central Bureau of Statistics of Buleleng Regency (2020), the total population in Buleleng Regency reached 791,813 people. That number increased by 167,688 people when compared to the population recorded in the 2010 population census. At that time the population in Buleleng reached 624,125 people. The increase in the population of Buleleng Regency in the last 10 years is $1.02 \%$. The increase in population tends to increase the need for land as a place of population activity, especially in Buleleng Regency. Therefore, land use planning should pay attention to the suitability of land use and area functions so that land use and management can be carried out sustainably. The focus of this research is the land use with its designation, as well as directions for land use planning to minimize the impact of land use that is not match with its designation.

Based on data from the Buleleng Regency Agriculture Service (2020) every year agricultural land in Buleleng Regency experiences a conversion, around 1.54 percent. In a period of two years, 2017-2018 and 2019-2020, the area of agricultural land that has undergone conversion has reached 168 hectares. Hundreds of hectares of agricultural land were turned into housing and turned commodities from rice fields to dry fields. If the rate of land conversion continues continuously, this will become a major threat to food security in the Buleleng Regency.

The Buleleng Regency Spatial Plan (2013-2033) is contained in the Buleleng Regency Regional Regulation No. 9 of 2013. The Buleleng Regency spatial plan is expected to be a guideline to direct the development and conservation of the area in Buleleng Regency by utilizing regional space in an efficient, effective, harmonious manner, aligned, balanced, and sustainable in order to improve the welfare of the community.

To map the level of suitability of land use and area functions to the Buleleng Regency Spatial Plan 2013-2033, this study will evaluate the suitability of land use and area functions to the spatial plan of Buleleng Regency 2013-2033. This evaluation aims to see the extent to which the level of suitability / non-compliance can be used as a guide in planning land use in accordance with its designation.

Apart from the physiographical conditions of Buleleng Regency, population growth with various activities will have implications in the form of pressure on the environment. Based on data from the Buleleng Regency (2020), the population growth rate in Buleleng Regency has reached 1.02 percent in the last 10 years. An increase of 167,688 people from 624,125 people in 2010 to 791,813 people in 2020 . This population growth certainly has implications for environmental resources. Mainly is the need for space as a place of activity.

The rate of population growth and exploitation of natural resources requires a better plan in managing the environment so that the evaluation of the function of the area becomes one of the partial efforts in the context of preparing plans and strategies for managing regional resources. In this case, thematic geospatial information related to the level of suitability of land use and area functions will play a very important role in various environmental management and conservation efforts, regional development planning, and become basic information in efforts to prepare anticipatory plans for environmental degradation in Buleleng Regency. 


\section{Methods}

\section{Research design}

The design used in this study is a descriptive design. Descriptive research is a research conducted with the main objective of providing an objective description or description of a situation. According to Sukmadinata (2011), descriptive research is aimed at describing or describing existing phenomena, both natural phenomena or human engineering. The phenomena described in this study are related to evaluate the suitability of land use with the Buleleng Regency Spatial Plan. The stages in this research are described as follows.

There are three stages in this research:

1) Preparation Stage

Activities in the preparatory stage are:

- Literature study, related to references and sources related to the topic being studied.

- Preparation of research tools and materials

- Preparation of data collection and media used.

2) Implementation Stage

In the implementation stage, the following are carried out:

- Observation and data collection in the field

- Processing and verifying data relevant to the problem being studied.

- Data analysis.

3) Stage After Implementation

The stages after the implementation of the activities include:

- Preparation of research reports.

- Report dissemination.

\section{Research sites}

This research was conducted in the Buleleng Regency, Bali Province. Astronomically, Buleleng Regency is located between $8^{\circ} 03^{\prime} 40^{\prime \prime}-8^{\circ} 23^{\prime} 00^{\prime \prime}$ South Latitude and $114^{\circ} 25^{\prime} 55^{\prime \prime}-$ $115^{\circ} 27^{\prime} 28^{\prime \prime}$ East Longitude.

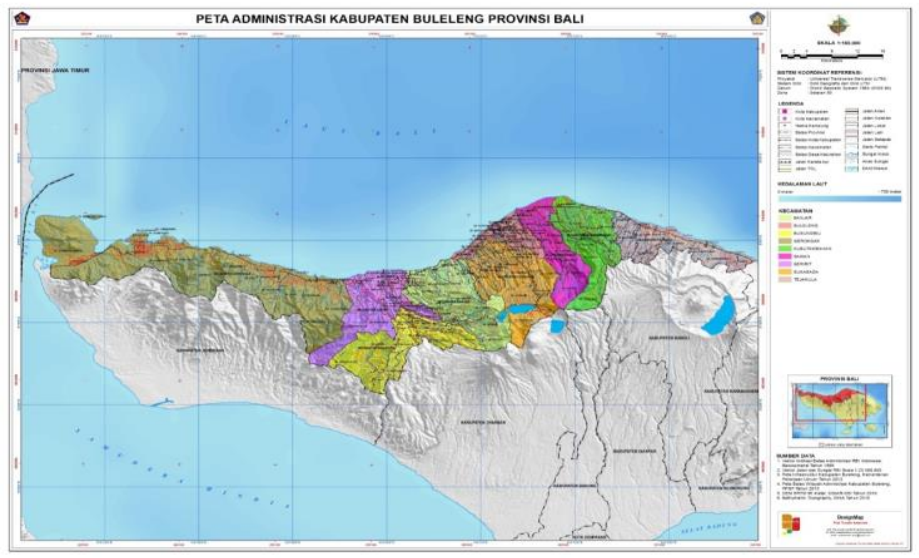

Figure 1 Research Location Map 


\section{Method of collecting data}

The data collected in this study consisted of primary data and secondary data.

The data collection method used is observation and document recording.

\section{Data Analysis}

The data analysis technique used in this research is descriptive-qualitative. The data analysis formulas in this study are as follows.

The data analysis used in this research is descriptive-qualitative analysis. By referring to the guidelines that are in accordance with the problems studied.

Data analysis in this study was conducted to 1) determine the level of suitability of land use in Buleleng Regency; 2) determine the function area of the Buleleng Regency; 3) determine the level of suitability of area functions with existing land uses. The formula used is as follows.

1) Determination of Area Function

According to the Decree of the Minister of Agriculture No. 837/Kpts/Um/11/1980 and No. : $683 / \mathrm{Kpts} / \mathrm{Um} / 8 / 1981$, the type of area function is determined based on the value of the land capability score and other special criteria. The area functions based on these criteria are grouped into 4 (four), namely 1) protected areas (code A); 2) buffer zone (code B); 3) annual crop cultivation area (code C); and 4) seasonal crop cultivation area (code D).

Determination of the function of the area refers to the Decree of the Minister of Agriculture No. $837 / \mathrm{Kpts} / \mathrm{Um} / 11 / 1980$ and No. : 683/Kpts/Um/8/1981, as shown in Table 1 below.

Table 1 Classification of Area Function Scores

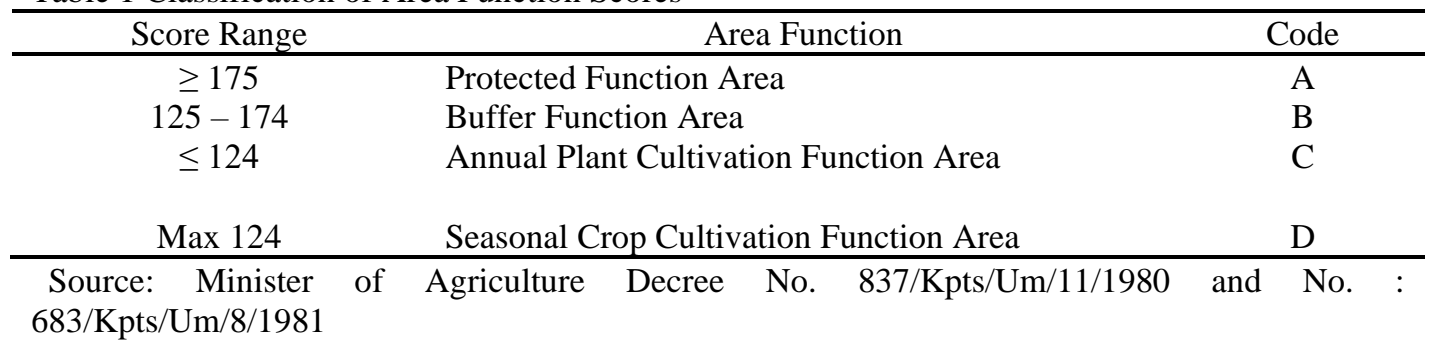

\section{Results and Discussion}

The results of this study are described in the following table.

Table 2 Identifikasi Kawasan Strategis Kabupaten (KSK) Berdasarkan RTRW

\begin{tabular}{lrlll}
\hline District Strategic Area & Interest & Location/Region Boundary & Suitability \\
\hline $\begin{array}{l}\text { Tourist } \\
\text { Area }\end{array}$ & Attraction & Economic Growth & $\begin{array}{l}\text { A developed tourist attraction } \\
\text { area }\end{array}$ & Suitable \\
$\begin{array}{l}\text { Merchant } \\
\text { urban area }\end{array}$ & function & Economic Growth & Urban Area Seririt & Suitable \\
\hline
\end{tabular}




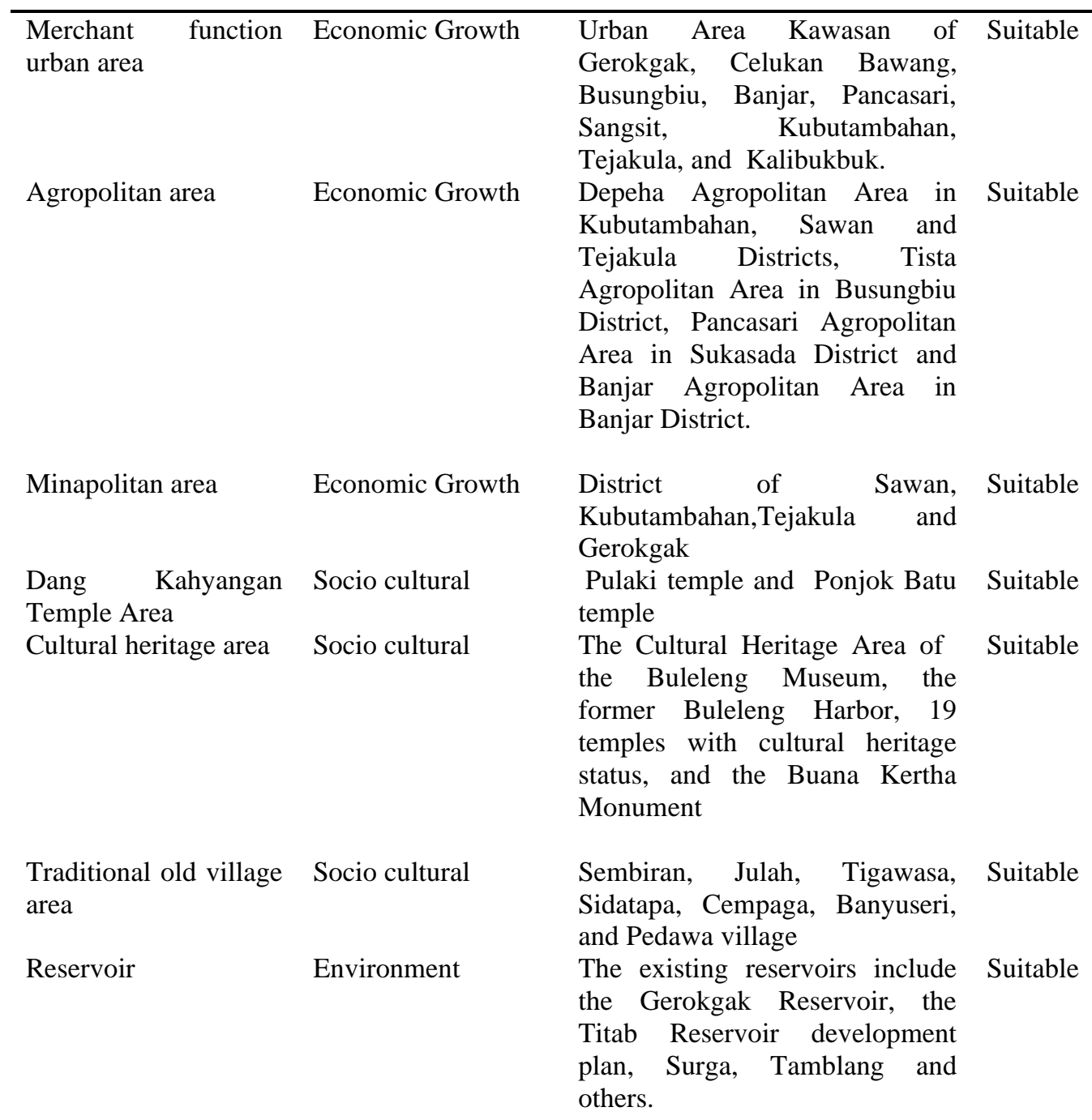

Based on the data in the table, it can be seen that there is a match between the spatial plan and development in the field.

Table 3 Identification of Spatial Plan Program Indications Related to Infrastructure Development

\begin{tabular}{|c|c|c|c|c|}
\hline No & Program & & Location & Information \\
\hline 1 & $\begin{array}{l}\text { Development } \\
\text { Bengkala }\end{array}$ & $\begin{array}{r}\text { of } \\
\text { Landfill }\end{array}$ & Bengkala village, Kubutambahan & Suitable \\
\hline
\end{tabular}




\begin{tabular}{|c|c|c|c|}
\hline & $\begin{array}{l}\text { Controlled } \quad \text { Landfill } \\
\text { System }\end{array}$ & & \\
\hline 2 & $\begin{array}{ll}\text { Urban } & \text { drainage } \\
\text { development } & \end{array}$ & $\begin{array}{l}\text { District of Seririt, Buleleng, Sukasada, } \\
\text { Sawan }\end{array}$ & Suitable \\
\hline 3 & $\begin{array}{l}\text { Development and } \\
\text { distribution of services } \\
\text { for urban settlement } \\
\text { infrastructure network } \\
\text { systems (drinking water, } \\
\text { drainage, waste water, } \\
\text { garbage, energy, roads) }\end{array}$ & $\begin{array}{l}\text { Tejakula, Kubutambahan, Sawan, } \\
\text { Buleleng, Sukasada, Banjar, Seririt, } \\
\text { Busungbiu, and Gerokgak }\end{array}$ & Suitable \\
\hline 4 & $\begin{array}{l}\text { Development and } \\
\text { distribution of services } \\
\text { for urban settlement } \\
\text { infrastructure network } \\
\text { systems (drinking water, } \\
\text { drainage, waste water, } \\
\text { garbage, energy, roads) }\end{array}$ & $\begin{array}{l}\text { Tejakula, Kubutambahan, Sawan, } \\
\text { Buleleng, Sukasada, Banjar, Seririt, } \\
\text { Busungbiu, Gerokgak }\end{array}$ & Suitable \\
\hline 5 & $\begin{array}{l}\text { Development of Urban } \\
\text { Green Open Space at } \\
\text { least } 30 \% \text { of urban areas }\end{array}$ & $\begin{array}{l}\text { Tejakula, Kubutambahan, Sawan, } \\
\text { Buleleng, Sukasada, Banjar, Seririt, } \\
\text { Busungbiu, Gerokgak }\end{array}$ & Suitable \\
\hline 6 & $\begin{array}{l}\text { Development of open } \\
\text { space around the holy } \\
\text { place }\end{array}$ & Gerokgak, Tejakula & Suitable \\
\hline 7 & $\begin{array}{l}\text { Development of open } \\
\text { spaces in cultural } \\
\text { heritage areas }\end{array}$ & $\begin{array}{l}\text { Buleleng, Sukasada, Kubutambahan, } \\
\text { Tejakula }\end{array}$ & Suitable \\
\hline
\end{tabular}

Based on the data in the table, it can be seen that there is a match between the spatial plan and development in the field. 


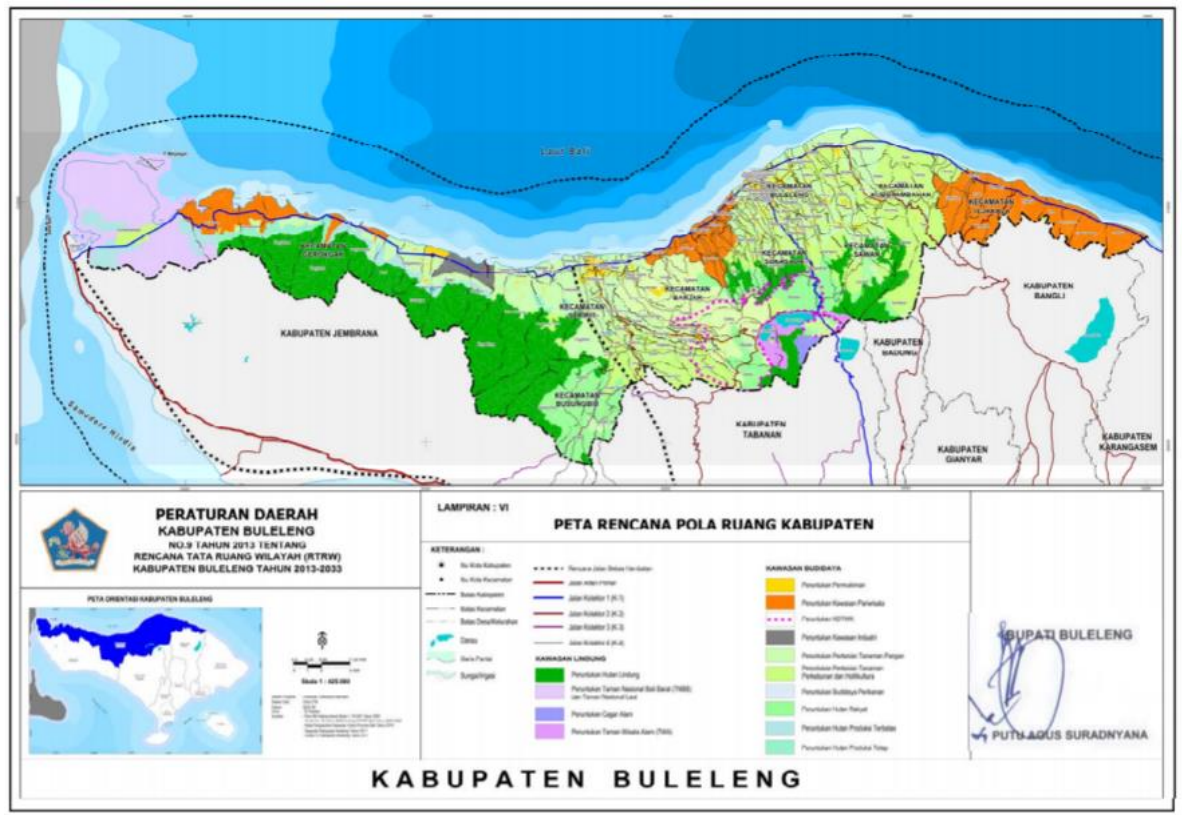

Figure 2 Space Pattern Map Of Buleleng Regency

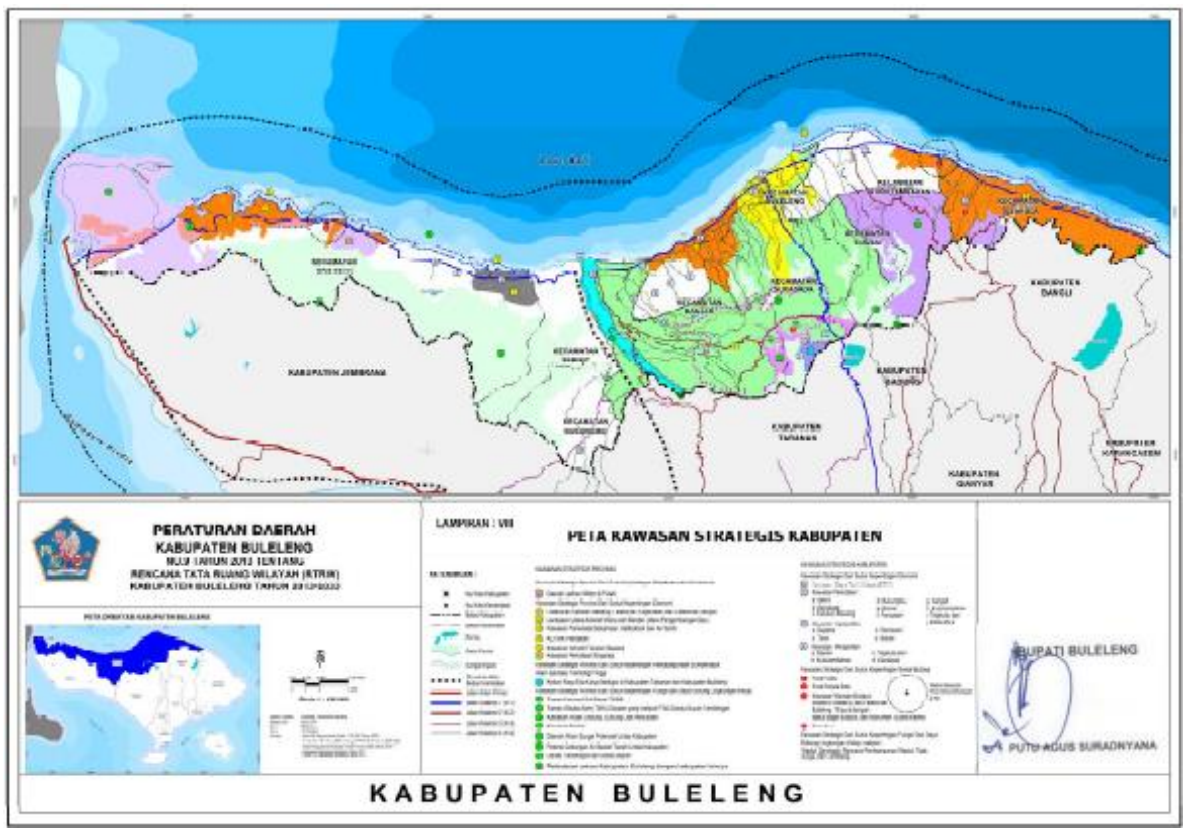

Figure 3 Strategic Area Map Of Buleleng Regency 


\section{References}

[1] Arsyad, Sitanala.: Soil and Water Conservation. Bogor: Bogor Agricultural University. (1989)

[2] Arsyad, Sitanala.: Soil and Water Conservation 2nd Edition Bogor: Bogor Agricultural University Press.(2006)

[3] Attachment to the Regulation of the Director General of Land Rehabilitation and Social Forestry Number: P.04

/ V-Set / 2009. Guidelines for Monitoring and Evaluation of Watersheds. Jakarta: Director General of RLPS (2009)

[4] Bakosurtanal.: Arc / Info Geographical Information Systems. Jakarta: Implementation of BAKOSURTANAL Education and Training. (1985)

[5] Bappeda Bali Province.: Hydrological Map of Bali Province. Denpasar: Bali Provincial Development Planning Agency. (2010)

[6] Bappeda Bali Province.: Map of Bali Province Slope Slope. Denpasar: Bali Provincial Development Planning Agency. (2010)

[7] Bappeda Bali Province.: Land Use Map of Bali Province. Denpasar: Bali Provincial Development Planning Agency. (2010)

[8] Badan Koordinasi Survei dan Pemetaan Nasional. 2001. Peta Rupabumi Digital Indonesia Lembar Singaraja, Gitgit, dan Sukasada. Jakarta: Bakosurtanal.

[9] Badan Pusat Statistik Kabupaten Buleleng. Buleleng Dalam Angka. Singaraja : BPS Kabupaten Buleleng. (2020)

[10] Bappeda Provinsi Bali. 2020. Peta Kemiringan Lereng Provinsi Bali Skala 1 : 250.000. Denpasar: Badan Perencanaan Pembangunan Daerah Provinsi Bali. 